\title{
Isolation and Characterization of a Novel Population of Progenitor Cells from Unmanipulated Rat Liver
}

\author{
M. Behnan Sahin, ${ }^{1}$ Robert E. Schwartz, ${ }^{1}$ Shannon M. Buckley, ${ }^{1}$ Yves Heremans, ${ }^{1}$ Lucas Chase, ${ }^{1}$ \\ Wei-Shou $\mathrm{Hu}^{2}{ }^{2}$ and Catherine M. Verfaillie ${ }^{1}$ \\ ${ }^{1}$ Stem Cell Institute and Department of Medicine and ${ }^{2}$ Department of Chemical Engineering, University of \\ Minnesota, Minneapolis, MN
}

\begin{abstract}
Widespread use of liver transplantation in the treatment of hepatic diseases is restricted by the limited availability of donated organs. One potential solution to this problem would be isolation and propagation of liver progenitor cells or stem cells. Here, we report on the isolation of a novel progenitor cell population from unmanipulated (that is, no prior exposure to chemicals and no injury) adult rat liver. Rat liver cells were cultured following a protocol developed in our laboratory to generate a unique progenitor cell population called liver-derived progenitor cells (LDPCs). LDPCs were analyzed by fluorescence-activated cell sorting, real-time polymerase chain reaction (RT-PCR), immunostaining and microarray gene expression. LDPCs were also differentiated into hepatocytes and biliary epithelium in vitro and examined for mature hepatic markers and urea and albumin production. These analyses showed that, LDPCs expressed stem cell markers such as cluster domain (CD)45, CD34, c-kit, and Thy 1 , similar to hematopoietic stem cells, as well as endodermal/hepatic markers such as hepatocyte nuclear factor (HNF)3 $\beta$, hematopoietically-expressed homeobox gene-1, c-met, and transthyretin. LDPCs were negative for OV-6, cytokeratins (CKs), albumin, and HNF1 $\alpha$. The microarray gene expression profile demonstrated that they showed some similarities to known liver progenitor/stem cells such as oval cells. In addition, LDPCs differentiated into functional hepatocytes in vitro as shown by albumin expression and urea production. In conclusion, LDPCs are a population of unique liver progenitors that can be generated from unmanipulated adult liver, which makes them potentially useful for clinical applications, especially for cell transplantation in the treatment of liver diseases. Liver Transpl 14:333-345, 2008. ๑ 2008 AASLD.
\end{abstract}

Received July 4, 2007; accepted September 30, 2007.

Diseases of the liver are common causes of morbidity and mortality in the world. ${ }^{1}$ Despite the high incidence of liver diseases that result in liver dysfunction and failure, current medical therapies are limited to supportive care, rather than curative approaches, with the possible exception of liver transplantation.

Liver transplantation is considered to be the standard treatment for end-stage liver disease. ${ }^{2}$ Unfortunately, its extensive application is restricted by the limited availability of donor organs. In addition, liver trans- plantation is associated with significant morbidity and mortality. As most liver disorders result from hepatocyte dysfunction, there has been great interest in transplantation of isolated hepatocytes. However, their clinical application is also dependent on the availability of good quality donor livers.

To overcome the problem of limited donor organs and to make hepatocytes available for other applications, several approaches to isolate and propagate liver stem cells or progenitor cells have been developed. ${ }^{3,4}$ It is

This article contains Supplementary Material available at http://www.mrw.interscience.wiley.com/suppmat/1527-6465/suppmat. Abbreviations: AAF, acetylaminofluorene; Ab, antibody; AFP, alpha-fetoprotein; BM, bone marrow; CD, cluster domain; CK, cytokeratin; ELISA, enzyme-linked immunoassay; FBS, fetal bovine serum; hex, hematopoietically-expressed homeobox gene; HNF, hepatocyte nuclear factor; LDPC, liver-derived progenitor cell; mRNA, messenger RNA; QRT-PCR, quantitative real-time polymerase chain reaction; RNA, ribonucleic acid; RT-PCR, real-time polymerase chain reaction.

Supported by the National Institutes of Health (U19 DK61244 and R01 HL073221) and by an award from the Alpha 1-Antitrypsin Foundation (to C.M.V.).

Address reprint requests to Catherine Verfaillie, M.D., Stem Cell Institute and Department of Medicine, University of Minnesota, 420 Delaware Street SE, MMC 716, Minneapolis, MN 55455. Telephone: 612-626-4916; FAX: 612-624-2436; E-mail: verfa001@ umn.edu

DOI 10.1002/lt.21380

Published online in Wiley InterScience (www.interscience.wiley.com). 
well known that the liver is capable of regenerating itself, ${ }^{4,5}$ chiefly because mature hepatocytes themselves can undergo multiple cell divisions in vivo. Under circumstances in which hepatocytes are unable to divide, or do so to a limited degree, such as in alcoholic liver disease, chronic cholestatic diseases, or hepatitis induced by viral infection, liver progenitors start to proliferate and differentiate into mature hepatocytes. ${ }^{3-5}$

A number of different liver progenitor/stem cell populations derived from adult animals have been described. Among these, the best known is a population of stem cells called oval cells. Oval cells proliferate in vivo following liver damage when the ability of hepatocytes to divide is inhibited. ${ }^{6,7}$ Oval cells are thought to be localized in biliary ductules (canal of Hering) in normal adult liver and have also been identified during liver embryonic development. ${ }^{8}$ Oval cells are bipotential and give rise to both hepatocytes and biliary ductal cells. ${ }^{9,10}$ Recent studies have identified many cell-surface markers for oval cells both in rodents and humans, including the hematopoietic markers Thy1.1, cluster domain (CD)34, Flt3-receptor, and c-kit. ${ }^{1-14}$ Oval cells also express alpha-fetoprotein (AFP), cytokeratin (CK) 19, and $\gamma$-glutamyl-transferase and stain positive with the monoclonal antibodies; OC.2, OV-6, and BD1. ${ }^{15}$ Until recently, it was believed that oval cells were exclusively derived from biliary ductal cells. However, this notion has been challenged by a number of studies suggesting that they may also be derived from bone marrow (BM). ${ }^{16-19}$ Therefore, it appears that oval cells can be obtained from multiple sources depending on the nature and severity of the liver injury as well as the methods used to isolate them. ${ }^{20,21}$ As oval cells are commonly isolated from liver following treatment with carcinogenic agents such as 3,5-diethoxycarbonyl-1.4dihydrocollidine, ${ }^{17}$ or from animals on a choline-deficient diets and treated with the hepatocarcinogenic agent $\mathrm{N}$-2-acetylaminofluorene (AAF), ${ }^{22,23}$ cells isolated by these protocols are often transformed, precluding their use for clinical transplantation. ${ }^{24-26}$

Here, we demonstrate that a population of progenitor cells exhibiting similarities to oval cells and hematopoietic stem cells can be isolated from noninjured liver of adult rats. These cells were characterized by RNA and protein analysis and by in vitro differentiation studies.

\section{MATERIALS AND METHODS Isolation of Liver Cells}

Liver cells from Sprague Dawley rats weighing 150 to 300 g (Jackson Labs, Bar Harbor, ME) were harvested by a modified 2 -step in situ collagenase perfusion technique as previously described. ${ }^{27}$ After digestion by collagenase, a single-cell suspension was obtained by filtering the liver cells through a $100-\mu \mathrm{m}$ sterile nylon gauze (Sigma-Aldrich, St. Louis, MO).The cells were then washed in phosphate buffered saline and centrifuged ( $50 \mathrm{~g}$ for 3 minutes) twice at room temperature prior to culture. The cells were not subjected to any fractionation (parenchymal versus nonparenchymal).

\section{Liver-Derived Progenitor Cell (LDPC) Culture Conditions}

Freshly isolated rat liver cells with viability between $50 \%$ and $90 \%$ were cultured in a medium consisting of 75\% Dulbecco's modified Eagle's medium (DMEM-LG; Cellgro, Herndon, VA) + 25\% MCDB 201 (Sigma-Aldrich) supplemented with 9\% rat serum (Equitech, Kerville, TX), 1\% fetal bovine serum (FBS; Hyclone, Logan, UT), $1 \mathrm{mg} / \mathrm{mL}$ of bovine serum albumin (BSA; Sigma), $100 \mu \mathrm{M}$ of $\beta$-mercaptoethanol (Gibco, Carlsbad, CA), 25 $\mathrm{mM}$ of 4-2-hydroxyethyl-1-piperazineethanesulfonic acid (HEPES; Cellgro), $5 \mathrm{mM}$ of Nicotinamide (Sigma), and penicillin $(100 \mu \mathrm{g} / \mathrm{mL}) /$ streptomycin $(100 \mu \mathrm{g} / \mathrm{mL}$; Invitrogen, Carlsbad, CA) on Type I collagen (Upstate Biotechnology, Danvers, MA) coated tissue culture plates or dishes at a density of $5 \times 10^{4}$ cells $/ \mathrm{mL}$ and $1 \times$ $10^{4}$ cells $/ \mathrm{cm}^{2}$ at $37^{\circ} \mathrm{C}$ in $7 \% \mathrm{CO}_{2}$ The seeding density was 33\% lower for younger rats that weighed less than $200 \mathrm{~g}$. The medium was changed by $80 \%$ on days 2 and 4. Subsequently, no media changes were made and LDPCs were allowed to appear and proliferate for the following 2 to 3 weeks. Between days 15 and 21, LDPCs were harvested for various studies. Karyotyping on LDPCs was done following standard protocols in our laboratory.

\section{LDPC Clonal Isolation}

LDPCs from bulk cultures were plated onto 96-well plates at a density of 1 cell/well in the conditioned media (100\%) obtained from bulk cultures. After 3 to 4 weeks, $10 \%$ of the wells had colonies of LDPCs consisting of 100 to 10,000 cells.

\section{Immunohistochemistry}

Immunocytochemical analysis of the cells was performed by using the streptavidin-biotin-peroxidase method or the streptavidin-biotin alkaline phosphatase method (Dako, Glostrup, Denmark) after fixation with 4\% paraformaldehyde. Mouse monoclonal antibodies (Abs) were against CK7 (Dako; 1:75), CK18 (Cymbus Biotechnology, Chandlers Ford, UK; 1:10), CK19 (Maine Biotechnology Services, Portland, OR; 1:75), desmin (ICN, 1:12, Costa Mesa, CA), and OV6 (gift from Dr. S. Sell, University of Texas Health Science Center, Houston, TX; 1:50). Rabbit antisera were against hepatocyte nuclear factor (HNF) 1 (Santa Cruz Biotechnology, Santa Cruz, CA; 1:50) and albumin (ICN/Cappel, Aurora, CO; 1:500). Goat antiserum was against HNF-3 $\beta$ (Santa Cruz Biotechnology; 1:50). Anti-mouse and anti-rabbit biotinylated secondary Abs were from Amersham Pharmacia (Uppsala, Sweden) and diluted 1:300. Anti-goat biotinylated secondary $\mathrm{Ab}$ was from Vector Laboratories (Burlingame, CA), and diluted 1:300. Color development was with the DAB + Substrate-Chromogen System (Dako) or with the New Fuchsin Substrate System (Dako). 


\section{Flow Cytometry}

For flow cytometric analysis, LDPCs, fresh BM, or fresh rat liver cells were stained sequentially with primary Abs: anti-rat granulocyte clone RP-1, anti-rat CD45R clone OX-33, anti-rat CD45 clone OX-1, and anti-rat CD3 clone $1 \mathrm{~F} 4$, and immunofluorescent secondary Abs and analyzed using a FACSCalibur (all from Becton Dickinson Pharmingen, San Diego, CA).

\section{Real-Time Polymerase Chain Reaction (RT- PCR) and Quantitative RT-PCR (QRT-PCR)}

RNA was extracted from $3 \times 10^{5}$ to $3 \times 10^{6}$ LDPCs. messenger RNA (mRNA) was reverse transcribed and complementary DNA (cDNA) underwent 40 rounds of amplification (ABI-Prism 7700; PerkinElmer/Applied Biosystems, Foster City, CA) as follows: 40 cycles of a 2-step PCR $\left(95^{\circ} \mathrm{C}\right.$ for 15 seconds, $60^{\circ} \mathrm{C}$ for 60 seconds) after initial denaturation $\left(95^{\circ} \mathrm{C}\right.$ for 10 minutes) with 2 $\mu L$ of DNA solution, $1 \times$ TaqMan SYBR Green Universal Mix PCR reaction buffer (Applied Biosystems). Primers used for amplification were obtained from various references. ${ }^{13,14,28-31}$ mRNA levels were normalized using GAPDH as housekeeping gene and compared with mRNA levels in fresh rat liver cells, rat BM, whole pancreas, pyloric stomach, and duodenum. Rat thyroid total RNA was obtained from Clontech (Mountain View, CA).

\section{Western Blot}

Protein lysates, obtained from LDPCs, rat liver cells, or rat BM were separated on $8.0 \%$ polyacrylamide electrophoresis gels (Sigma-Aldrich). Gels were transferred to membrane blots, which were incubated with Abs against CK18 (Cymbus Biotechnology, Chandlers Ford, UK; 1:100), CK19 (Maine Biotechnology ServicesPortland, ME; 1:200), CD34 (Santa Cruz Biotechnology; 1:250), CD117 (Santa Cruz Biotechnology; 1:250). Blots were washed and incubated with a goat antimouse or anti-rabbit horseradish peroxidase-conjugated antibody (1:10,000 and 1:20,000 dilution; Amersham Biosciences, Piscataway, NJ). Bands were visualized by means of an enhanced chemiluminescence detection system (Amersham Biosciences).

\section{Liver Differentiation from LDPCs}

LDPCs were harvested from the cultures between days 15 and 21 by tapping the dishes gently to avoid contaminating the samples with adherent cells. Cells were plated on collagen-coated tissue culture plates at a density of $1 \times 10^{5}$ cells $/ \mathrm{cm}^{2}$ in expansion medium supplemented with 10\% FBS (instead of 1\% FBS and 9\% rat serum), $20 \mathrm{ng} / \mathrm{mL}$ of hepatocyte growth factor (HGF; R\&D Systems, Minneapolis, MN), and $100 \mathrm{nM}$ of dexamethasone. The medium was changed on days 7 and 14. Cultures were analyzed between days 21 and 42 .

\section{Urea Production Assay}

Urea concentrations were determined by colorimetric assay (Sigma-Aldrich) per manufacturer's instructions. Briefly, $100 \mu \mathrm{L}$ of culture supernatant or media was added to a cuvette; then $0.5 \mathrm{~mL}$ of a urease solution was added and incubated for 20 minutes; $1 \mathrm{~mL}$ of phenol nitroprusside followed by $1 \mathrm{~mL}$ of alkaline hypochlorite was then added. A total of $5 \mathrm{~mL}$ of water was added to the cuvette and the sample was mixed and allowed to incubate for 30 minutes before the absorbance reading was examined. Rat hepatocytes grown in monolayer were used as positive controls and fresh culture medium used as negative control. As the assay measures ammonia metabolized from urea, samples were assessed before and after urease addition. No urea or ammonia was detected in culture medium alone.

\section{Albumin Enzyme-Linked Immunoassay (ELISA)}

Rat albumin concentrations were determined by a competitive enzyme linked immunoassay (ELISA) described previously for human and mouse albumin measurements with substitution of human or mouse albumin and anti-human or anti-mouse albumin Abs for the rat components where appropriate. Peroxidase conjugated anti-human albumin and reference human albumin were from Cappel. Peroxidase-conjugated and affinitypurified anti-mouse albumin and reference mouse albumin were from Bethyl Laboratories (Montgomery, TX). To ensure specificity of the ELISA, human, mouse, and rat Abs were incubated for 2 hours at $37^{\circ} \mathrm{C}$ with $3 \%$ bovine serum albumin in distilled water $\left(\mathrm{dH}_{2} \mathrm{O}\right)$.

\section{Processing of RNA Samples and Oligonucleotide Microarray Analysis}

Total cellular RNA was isolated from LDPCs and rat liver cells using the PicoPure RNA Isolation Kit (Arcturus, Mountain View, CA) per the manufacturer's instructions. A total of 1 million LDPCs and hepatocytes were placed directly into $100 \mu \mathrm{L}$ extraction buffer provided with the PicoPure RNA Isolation Kit prior to RNA isolation. Labeled complementary RNA (cRNA) was generated by one round of linear amplification using the RiboAmp OA RNA Amplification Kit (Arcturus) followed by labeling with the Enzo Bioarray HighYield RNA Transcript Labeling Kit (Enzo Life Sciences, Farmingdale, $\mathrm{NY}$ ) according to the manufacturer's instructions. Samples were hybridized to Affymetrix Rat 2302.0 chips (Santa Clara, CA), washed and scanned at the University of Minnesota Affymetrix Microarray Core Facility as described in the Affymetrix GeneChip Expression Analysis Technical Manual. Oligonucleotide microarray data analysis. Affymetrix Rat 2302.0 arrays were processed using GeneData Refiner software (Basel, Switzerland) to assess overall quality. Feature intensities for each chip were condensed into a single intensity value per gene using algorithms in the Microarray Analysis Suite, the Affymetrix Statistical Algorithm (MAS 5.0). 
Day 10
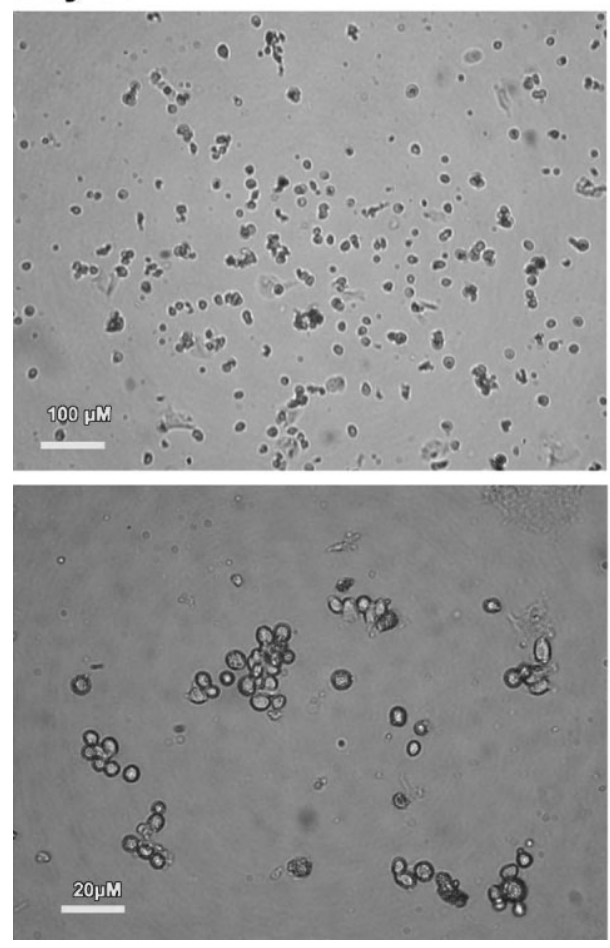

Day 21
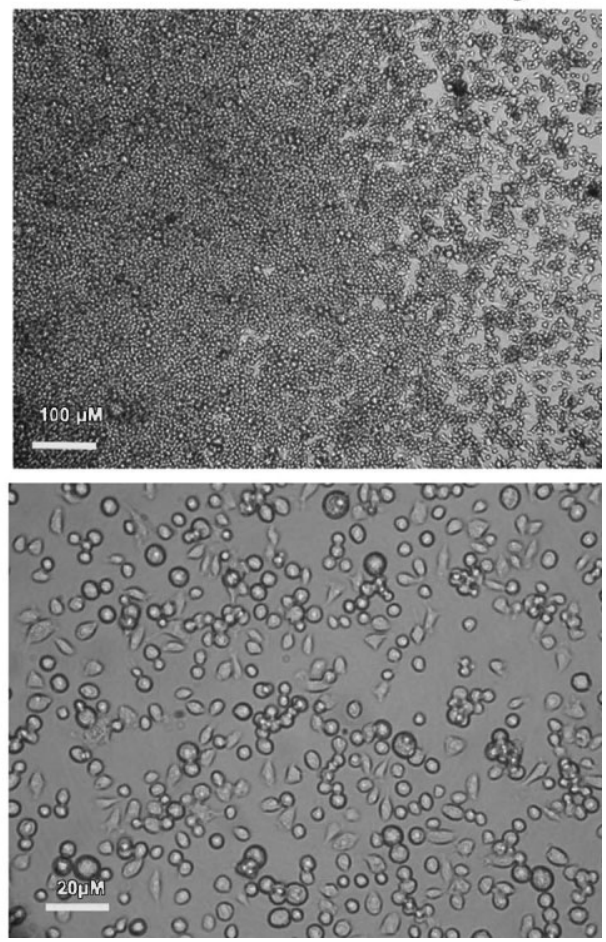

Figure 1. Emergence of liver-derived progenitor cells (LDPCs) in primary liver cultures. By day 10 the majority of hepatocytes die out and an entirely distinct population of cells appears. These cells, LDPCs, rapidly repopulate the cultures forming very dense colonies by day 21 . At this point LDPCs constitute $>95 \%$ of the cells, the rest are fibroblast-like cells while no hepatocytes remain in the cultures.

Expression data was analyzed using GeneData's Expressionist and Microsoft Excel (Redmond, WA). Differential gene expression for comparison of LDPCs versus hepatocytes was defined by using a paired Student $t$ test with a threshold of $P<0.05$, and a paired fold change was used to rank gene lists. Differentially expressed genes were classified according to their respective gene pathways and gene ontologies when available by using the web-based Affymetrix NetAffx analysis tool (Affymetrix) and the National Institutes of Allergy and Infectious Disease Database for Annotation, Visualization, and Integrated Discovery analysis tool (http:// apps 1.niaid.nih.gov/david).

\section{Microarray QRT-PCR Confirmation}

Labeled cRNA was reverse-transcribed to generate cDNA using SuperScript II Reverse Transcriptase (Invitrogen, Carlsbad, CA) according to the manufacturer's instructions. QRT-PCR was performed using the ABI-Prism 7000 Sequence Detection System (Applied Biosystems), as described earlier.

\section{Colony-Forming Assay and Stromal Cell Cocultures}

LDPCs and total rat BM were plated in methylcellulose medium (M3234; Stem Cell Technologies, Seattle, WA) supplemented with $20 \mathrm{ng} / \mathrm{mL}$ recombinant stem cell factor, $10 \mathrm{ng} / \mathrm{mL}$ interleukin-3, $10 \mathrm{ng} / \mathrm{mL}$ mouse inter- leukin-6 (all from PeproTech, Rocky Hill, NJ), and 3 $\mathrm{U} / \mathrm{mL}$ human erythropoietin (Amgen Inc., Thousand Oaks, CA). Total rat BM and LDPCs were plated at 1000, 5000, and 10,000 cells $/ \mathrm{mL}$. All cultures were incubated at $37^{\circ} \mathrm{C}$ and $5 \% \mathrm{CO}_{2}$. Colonies were counted between day 10 and 14. For stromal cell cocultures, LDPCs were plated on top of irradiated stromal cells, AFT024, ${ }^{32}$ UG26-1B6, and EL08-1D2, and cultured at $37^{\circ} \mathrm{C}$ with $5 \% \mathrm{CO}_{2}$ for 7 to 14 days. Cells were then analyzed for hematopoietic lineage markers by flow cytometry.

\section{Animal Transplantations}

RAG2 $\gamma \mathrm{c}$ immunodeficient mice from Taconic (Hudson, NY) were cotransplanted with lineage + BM from green fluorescent protein-positive $\mathrm{C} 57 \mathrm{Bl} / 6$ mice and either LDPCs or rat BM. All protocols involving mice were approved by the Institutional Animal Care and Use Committee at the University of Minnesota and all animals received humane care. Recipient mice were irradiated at 750 cGy prior to transplantation. Then, $1 \times$ $10^{6} \mathrm{BM}$ mononuclear cells from Sprague-Dawley rat or $1 \times 10^{6}$ LDPCs were mixed with $1 \times 10^{5}$ lineage + mouse BM cells and injected via the tail vein. After 2 months, peripheral blood cells were obtained, and after 4 months, BM was obtained, and examined for rat hematopoietic markers by flow cytometry. 
A)

C-kit

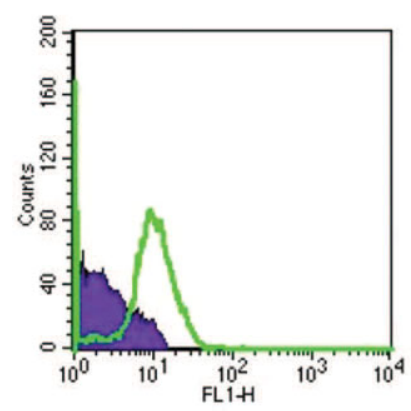

RT1A

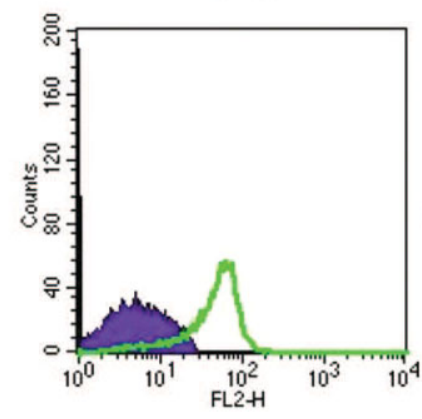

B)

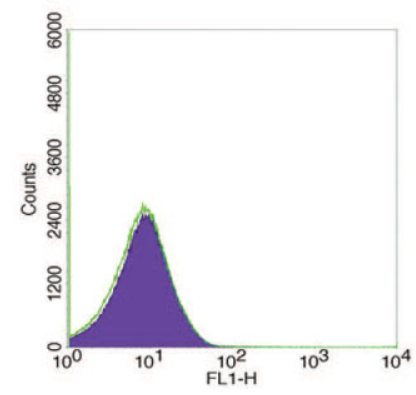

Thy-1.1

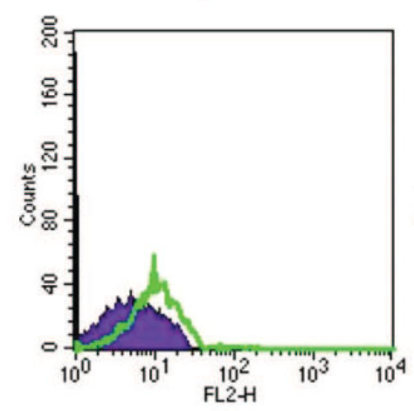

RT1B

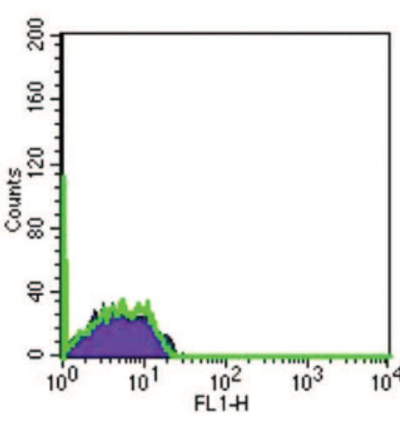

Thy1.1

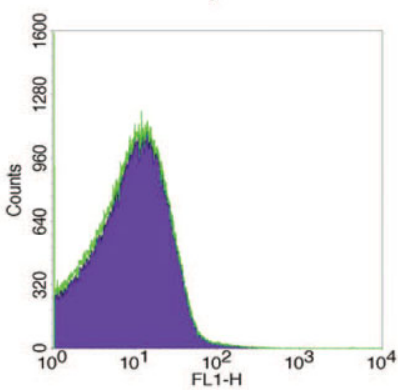

CD45

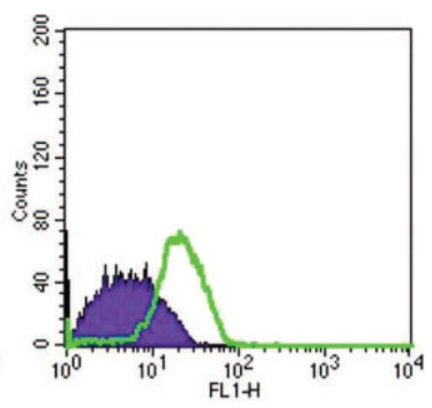

Granulocyte

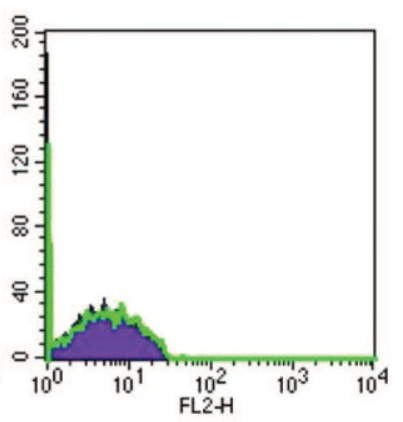

CD45

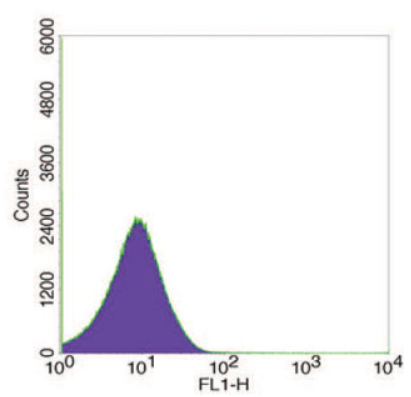

Figure 2. (A) Flow cytometric analysis of liver-derived progenitor cells (LDPCs): Antibodies (Abs) against ckit, Thy-1, CD45, RT1A, RT1B, granulocyte, or control immunoglobulin G (IgG). Cells were analyzed by flow cytometry. Plots show isotype control IgG staining profile (dark solid blue) versus specific $\mathrm{Ab}$ staining profile (thick green line). Each analysis shown is 1 representative example from a total of 10 analyses. Values on the x-axis indicate intensity log. LDPCs express c-kit, Thy-1, CD45, and RT 1A but not RT1B or granulocyte markers. c-kit, Thy-1, and CD45 are expressed classically on hematopoietic cells and some oval cell populations. LDPCs express RT1A, an equivalent of Class I majorhistocompatibility antigen (MHC) while they do not express RT1B, an equivalent of Class II MHC. In addition, they do not express a granulocyte marker. (B) Flow cytometric analysis of freshly isolated single-cell preparation from liver.

\section{RESULTS}

\section{Generation of LDPCs from Primary Adult Liver Cells}

When liver cells were plated, they quickly attached to the dishes and formed monolayer cultures with a confluency of 10 to $20 \%$ within 48 hours. Following media change on day 4, the large hepatic epithelial cells gradually died and by day 10 approximately $10 \%$ of the cells remained alive (Fig. 1). Between day 7 and day 10, a population of cells emerged that were much smaller than the original hepatocytes (average size 5-10 $\mu \mathrm{m}$ in diameter), with round to oval morphology. Over the next 7 to 14 days, the number of the small, round cells increased rapidly, reaching an average maximum density of 1 to $2 \times 10^{4}$ cells $/ \mathrm{cm}^{2}$, representing 2 to 4 LDPCs generated per liver cell plated (range, $0.5-3 \times 10^{4}$ cells/ $\mathrm{cm}^{2}$ ). At this density, they formed tightly packed, round cell clusters. Such cultures also contained 1 to $5 \%$ fibroblast-like cells that were not present in the cultures immediately after plating hepatocytes. Generation of LDPCs is highly reproducible $(n>50)$ provided that the actual viable cell density in culture at 24 hours is optimal (5-10 $\times 10^{3}$ cells $\left./ \mathrm{cm}^{2}\right)$. Attempts at expanding LDPCs beyond day 21, however, resulted in no further increase in their number (that is, LDPCs were generated each time from a fresh liver harvest and not passaged). 

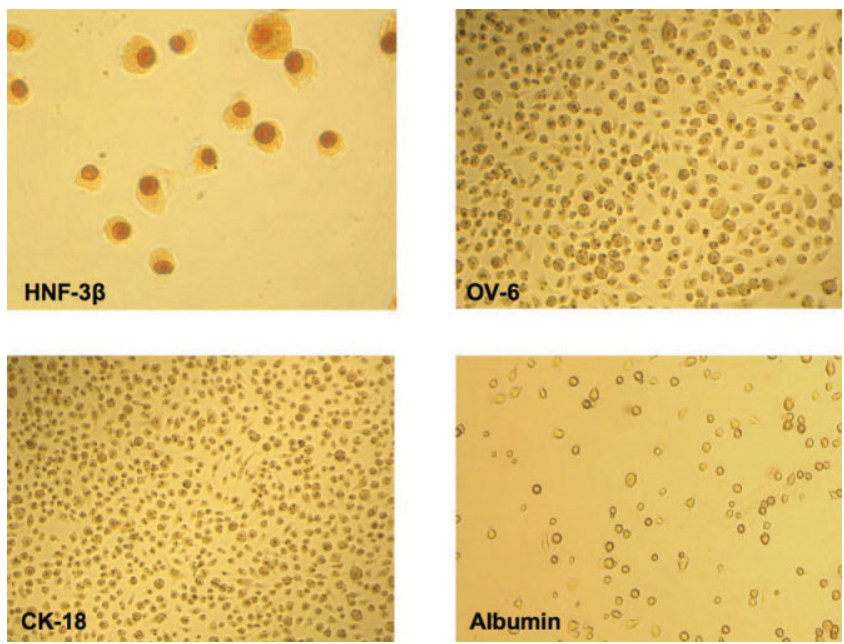

Figure 3. Because of high autofluorescence, immunohistochemical analysis (IHC) was done on liver-derived progenitor cells (LDPCs). They stain positive for hepatocyte nuclear factor (HNF)-3 3 . LDPCs are negative for oval cell marker OV-6, stellate cell marker desmin, and hepatocyte marker CK-18 and albumin. They also stain negative for biliary epithelial markers CK-7 and 19 (not shown).

\section{Flow Cytometric and Karyotypic Analyses of LDPCs}

Standard karyotypic analysis of LDPCs demonstrated a normal karyotype ( $\mathrm{n}=5$; data not shown). Flow cytometric analysis showed that LDPCs were CD45, c-kit, Thy-1 (dim), and RT1A positive while they were negative for RT1B, granulocytic (Fig. 2A), CD3 and erythroid markers (data not shown). Flow cytometric analysis of fresh liver samples failed to show a population of cells with similar phenotype $(\mathrm{n}=3)$ (Fig. 2B).

\section{Immunohistochemistry on LDPCs}

We used immunohistochemistry to further characterize the phenotype of LDPCs. They were negative for CK18, albumin, OV-6 (Fig. 3A), CK7, CK8, CK19, desmin, and HNF- $1 \alpha$ (not shown). LDPCs were positive for HNF-3 $\beta$ (Fig. 3A) and GATA-4 (not shown), whereas staining for AFP was inconclusive. In contrast, the mature control hepatocytes were CK7, CK19, desmin, and OV-6 negative while positive for albumin, HNF-3 $\beta$, GATA- 4 , and HNF- $1 \alpha$, whereas biliary ductal cells stained positive for CK19 and OV-6 (data not shown). The small number of fibroblast-like cells found adherent to the plates stained positive for desmin, but were negative for CK7, CK18, CK19, OV-6, albumin, HNF-3 $\beta$, GATA-4, and HNF- $1 \alpha$ (not shown).

\section{Western Blot and RT-PCR Analyses}

Western blot confirmed that CD34 and c-kit proteins were present in LDPCs whereas CK18 and CK19 were absent $(\mathrm{n}=5$ ) (Fig. 4). QRT-PCR analysis confirmed our immunohistochemical and flow cytometric data (Table 1). Transcripts for c-Kit, Thy 1, and CD34 were expressed in LDPCs at levels between 1 and $2.5 \%$ that of whole BM, while no expression of these markers could be detected in fresh liver samples. LDPCs expressed moderate levels of transcripts for transthyretin and very low levels for AFP. In addition, LDPCs expressed high levels of c-met mRNA relative to hepatocytes and CXCR4 mRNA relative to BM. LDPCs did not have any appreciable levels of transcripts for CK18, CK19, Albumin, and HNF-1. QRT-PCR was also used to examine expression of genes associated with other endodermally-derived tissues such as thyroid transcription factor-1, expressed in thyroid tissue; gastrin, expressed in pyloric stomach; secretin, expressed in the duodenum; caudal related homologs 1 and 2 (CDX-1 and CDX-2), expressed in the duodenum; musashi, expressed in the liver; hematopoietically-expressed homolog gene (HEX1), expressed in the liver; and pancreatitis-associated protein, expressed in the pancreas (Table 2). LDPCs did not express thyroid transcription factor-1, secretin, gastrin, and CDX-1 but expressed musashi and HEXl at $1200 \%$ and $6 \%$ relative to hepatocytes. LDPCs also expressed CDX2 and pancreatitis-associated protein-1 at low levels while hepatocytes did not express either of these markers. As some have suggested that oval cells may be BM-derived and LDPCs express hematopoietic cell surface markers, we used QRT-PCR to examine expression of genes known to be important in hematopoiesis such as Gata1, Gata2, Tal1, Lmo2, Pu.1, Mll1, and Runx1. LDPCs did not express Gatal but expressed Gata2 and Tal1 at very low levels and expressed Lmo2, Pu.1, and Runxl at high levels (Table 1). LDPCs have remained phenotypically stable for up to 8 weeks when cultured in medium that was partially $(75 \%)$ changed with fresh medium once a week (data not shown).

\section{Clonal Generation of LDPCs}

LDPCs from 2-week-old cultures were subcloned at 1 cell/well ( $\mathrm{n}=3$ isolations) in conditioned media (100\%)

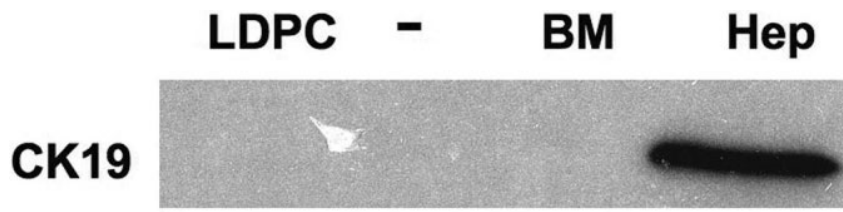

\section{CK18}

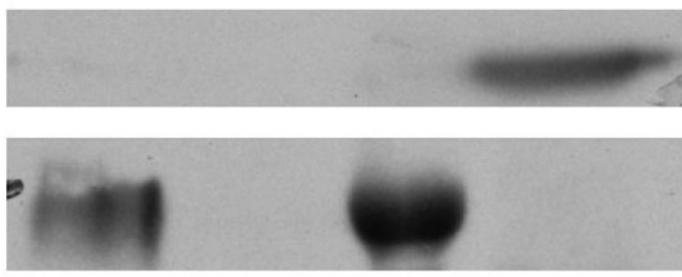

\section{C-Kit}

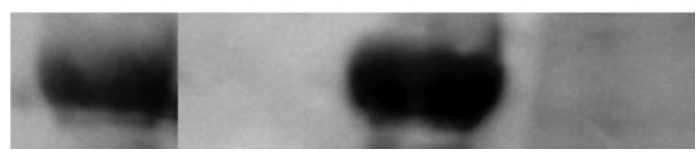

Figure 4. Protein lysates were transferred to Immuno-Blot polyvinylidene fluoride (PVDF) membrane, and incubated overnight with antibodies (Abs) against CK19, CK18, CD34, C-kit, or $\beta$-actin. Liver-derived progenitor cells (LDPCs); (-), negative control; BM, rat bone marrow; Hep, rat hepatocytes. Rat BM and rat hepatocyte used as control. 
TABLE 1. mRNA Expression Profile of LDPCs for Various Stem Cell and Endodermal/Hepatic Markers: Quantitative RT-PCR Analysis of LDPCs

\begin{tabular}{|c|c|c|c|c|c|c|}
\hline & \multirow[b]{2}{*}{$\begin{array}{r}\text { LDPCs } \\
(+/-) \\
\end{array}$} & \multirow[b]{2}{*}{$\begin{array}{r}\text { Hepatocytes } \\
(+/-)\end{array}$} & \multirow[b]{2}{*}{$\mathrm{BM}(+/-)$} & \multirow[b]{2}{*}{$\begin{array}{r}\text { Cycle } \\
\text { Number }\end{array}$} & \multicolumn{2}{|r|}{ LDPCs } \\
\hline & & & & & $\begin{array}{r}\text { Relative } \\
\text { Expression of } \\
\text { Hepatocytes }\end{array}$ & $\begin{array}{r}\text { Relative } \\
\text { Expression } \\
\text { of BM }\end{array}$ \\
\hline CD45 & + & - & + & 31 & NT & $3 \%(\mathrm{BM})$ \\
\hline CKit & + & - & + & 33 & NE (Hep) & $2 \%(\mathrm{BM})$ \\
\hline CD34 & + & - & + & 29 & NE (Hep) & $2 \%(\mathrm{BM})$ \\
\hline Thy 1 & + & - & + & 29 & NE (Hep) & $2 \%(\mathrm{BM})$ \\
\hline CXCR4 & + & - & + & 24 & NE (Hep) & $13 \%(\mathrm{BM})$ \\
\hline Gata 1 & - & - & + & 38 & $\mathrm{NT}$ & $\mathrm{NE}$ in $\mathrm{LDPC}$ \\
\hline Gata2 & + & NT & + & 30 & NT & $<1 \%$ \\
\hline Tall & + & NT & + & 33 & NT & $<1 \%$ \\
\hline Lmo2 & + & NT & + & 20 & NT & $2 \%$ \\
\hline Pu. 1 & + & NT & + & 20 & NT & $3 \%$ \\
\hline Mll1 & + & NT & + & 21 & NT & $<1 \%$ \\
\hline Runx1 & + & NT & + & 24 & NT & $2 \%$ \\
\hline CK19 & - & - & - & 34 & 1\% (Liver) & $\mathrm{NE}(\mathrm{BM})$ \\
\hline CK18 & - & + & - & 33 & 2\% (Hep) & $\mathrm{NE}(\mathrm{BM})$ \\
\hline $\mathrm{AFP}$ & $+/-$ & + & - & 33 & $0.1 \%$ (Hep) & $\mathrm{NE}(\mathrm{BM})$ \\
\hline Alb & - & + & - & 35 & $0 \%$ (Hep) & $\mathrm{NE}(\mathrm{BM})$ \\
\hline TTR & + & + & - & 25 & $0.01 \%$ (Hер) & $\mathrm{NE}(\mathrm{BM})$ \\
\hline HNF-1 & - & + & - & 34 & 0\% (Hep) & $\mathrm{NE}(\mathrm{BM})$ \\
\hline HNF3 $\beta$ & + & + & - & 28 & 3\% (Hep) & $\mathrm{NE}(\mathrm{BM})$ \\
\hline cMet & + & + & - & 21 & $112 \%$ (Нер) & $\mathrm{NE}(\mathrm{BM})$ \\
\hline
\end{tabular}

NOTE: LDPCs were harvested and subjected to quantitative RT-PCR with the SYBR green method for mRNAs as indicated. The mRNA levels were normalized with rat glyceraldehyde 3-phosphate dehydrogenase as a housekeeping gene. + or - indicates whether the sample was positive or negative for the respective marker. Cycle number is the PCR cycle at which the PCR product reached a certain specified fluorescence intensity, which was kept constant for all samples. The background level of the assay was around 34 to 40 cycles, depending on the specific primer. The relative expression values represent LDPC mRNAs relative to hepatocytes or BM where indicated. For c-kit, CD34, Thy-1, CXCR4, Gata2, Tal1, Lmo2, Pu.1, and Runx1, relative expression numbers are relative to BM as they are not expressed by hepatocytes. Likewise, CK19, CK18, AFP, albumin, TTR, HNF-1, HNF-3 $\beta$, and cMET are relative to hepatocytes as they are not expressed by BM. Data in this table are representative examples of 7 RT-PCR analyses.

Abbreviations: AFP, alpha-fetoprotein; BM, bone marrow; CK, cytokeratin; LDPC, liver-derived progenitor cell; mRNA, messenger RNA; NE, not expressed; NT, not tested; PCR, polymerase chain reaction; RT-PCR, real-time polymerase chain reaction; CXCR4, chemokine receptor 4; Gata, globin transcription factor; Tal1, T-cell acute leukemia 1; Lmo2, LIM domain only 2; Pu.1, putative oncogene Spi-1; Mll1, mixed lineage leukemia-1; Runx1, runt-related transcription factor 1; TTR, transthyretin; cMet, mesenchymal epithelial transition factor.

obtained from bulk cultures. After 3 to 4 weeks, we could detect colonies of 100-10,000 LDPCs in 10\% of the wells. By RT-PCR, clonal LDPCs were CD45, c-kit, CD34, Thy-1 CXCR4, AFP, cMet, HNF-3 $\beta$, musashi, hex, and CDX2 mRNA positive, but did not express CK18, CK19, or albumin transcripts identical to LDPCs from bulk cultures (not shown).

\section{Microarray Analysis of LDPC}

In order to better characterize and compare LDPC with other known populations of hepatocyte progenitor or stem cells, we evaluated the transcriptome of LDPCs in comparison with that of the liver cells that gave rise to LDPCs using Affymetrix gene arrays. The fidelity of our microarray results was confirmed using QRT-PCR (data not shown). The expressed gene profile of 5 different LDPC isolations was highly consistent $\left(\mathrm{R}^{2}\right.$ value $\left.>0.90\right)$ but differed significantly from that of the fresh hepatocytes used to initiate the cultures $\left(\mathrm{R}^{2}\right.$ value $\left.\sim 0.71\right)$ (Fig. $5 \mathrm{~A}$ and $\mathrm{B})$. We identified 4636 total probe sets that were differentially expressed between LDPCs and hepatocytes (paired Student $t$ test; $P<0.05$; data not shown) of which 1211 gene transcripts were greater than 1.5fold differentially expressed. Of these, 577 transcripts were more highly expressed in LDPCs and 634 in hepatocytes (Supplemental Table 1). Compared with hepatocytes, LDPCs did not express, or expressed at much lower levels, genes encoding for hepatic metabolic and secretory functions, such as albumin, transthyretin, and transferrin; enzymes associated with glycogen production and cholesterol and fatty acid production, and genes associated with the detoxifying function of hepatocytes, such as the cytochrome $2502 \mathrm{~A}-2 \mathrm{E}$ family of genes. Of the 577 transcripts expressed more highly in LDPCs, more than $50 \%$ of genes were unclassified and 
TABLE 2. mRNA Expression Profile of LDPCs for Various Stem Cell and Endodermal/Hepatic Markers: Expression of Some Endodermal/Gut Markers in LDPCs

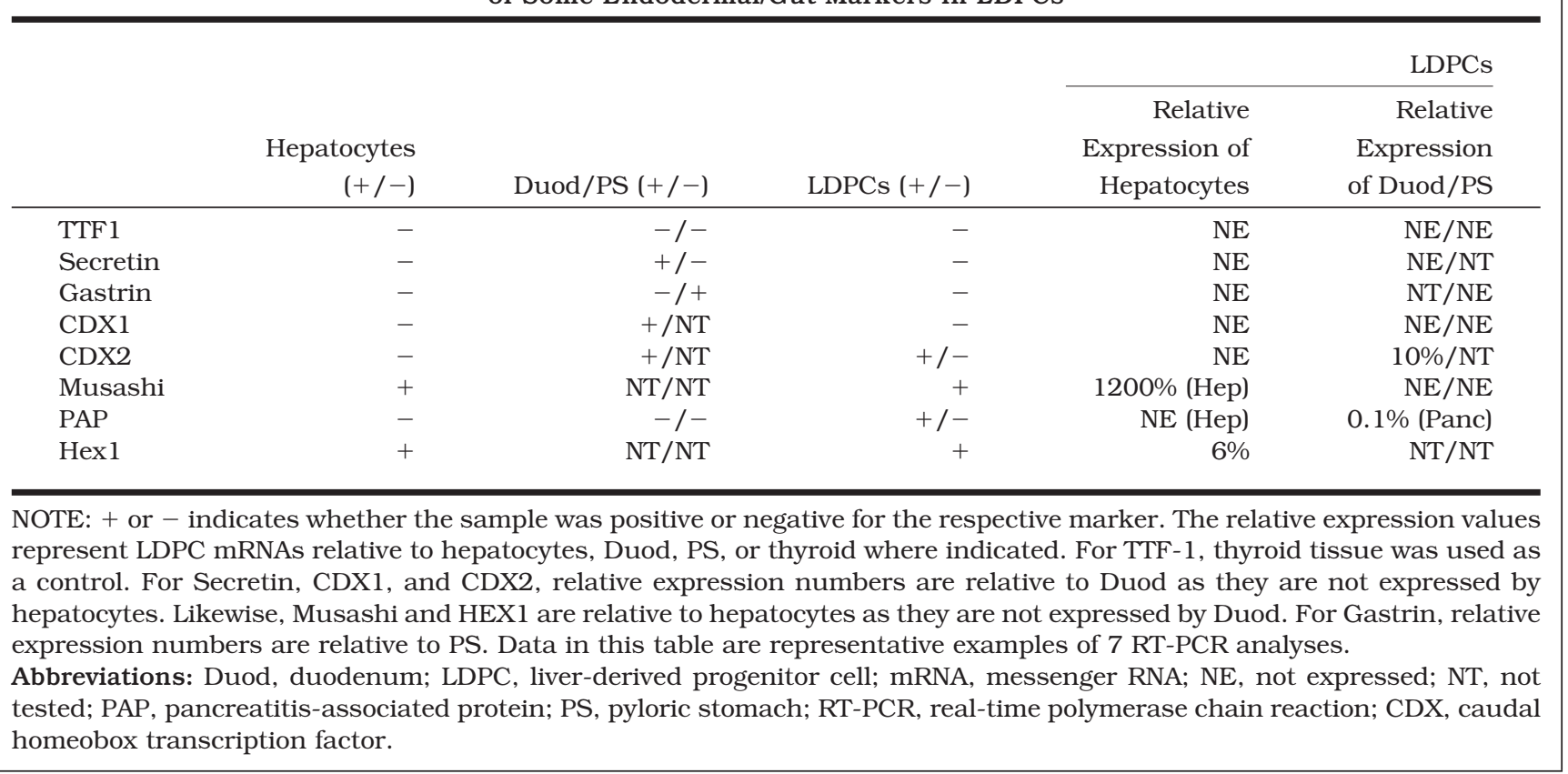

lacked functional annotation (Fig. 5C). Of the 236 annotated genes, there were 211 unique gene transcripts, 49 of which encode for genes known to be important in liver regeneration, which represents a disproportionate enrichment (Supplemental Table 2).

We also compared the genes more highly expressed in LDPCs than hepatocytes with published gene expression data on epithelial stem and progenitor cells from liver or the gastrointestinal tract (Supplemental Table 3). LDPC gene expression is very similar to other liver and epithelial progenitor cell populations. Epithelial membrane protein 1 , found to be highly expressed in all other epithelial progenitor cell populations was highly expressed in LDPC. ${ }^{33}$ Cimica et al., ${ }^{34}$ who used serial analysis of gene expression to compare cells from animals that underwent partial hepatectomy +2 -AAF versus sham laparotomy + 2-AAF administration, described 27 genes that were more highly expressed and 14 genes that were expressed at lower levels in oval cells compared to normal liver cells. Six of 27 more highly expressed and 6/14 genes less expressed in oval cells were also more highly or significantly less expressed, respectively, in LDPCs compared with hepatocytes. ${ }^{34}$ An additional 14 genes more highly expressed in LDPC were common gene family members of genes found in oval cells in the Cimica study. ${ }^{34}$ Comparing LDPCs with BM-derived hepatic stem cells described by Wang et al. ${ }^{35}$ indicates that 8 genes and 13 family members are in common between LDPCs and BM-derived hepatic stem cells. Further validation that LDPCs represent a population of early progenitors comes from comparison with the transcriptome of small intestinal epithelial progenitors and gastric progenitors. ${ }^{32,36}$ A total of $22 \%$ of LDPC genes had identity with the small intestinal epithelial progenitors data set, which increased to $29 \%$ if we also include genes from the same family.

\section{Differentiation of LDPCs into Hepatocytes and Ductal Cells}

LDPCs collected from cultures by gentle tapping (in order to avoid any attached fibroblast-like or epithelial cells) were cultured on Type I collagen in 10\% fetal bovine serum and HGF for 21 to 42 days. A total of 10 to $20 \%$ of the cells differentiated into hepatocytes during the first 3 to 4 weeks but with longer culture period (up to 6 weeks) this percentage reached 60 to $70 \%$ (Fig. $6 A)$. The differentiated cells stained positive for albumin, CK-18, and HNF-1 $\alpha$, consistent with hepatocyte differentiation (Fig. 6B). In some differentiation cultures, LDPCs also formed lumen-like structures that were surrounded by CK19 positive cells, a marker of biliary duct epithelium, albeit at a lower frequency (Fig. $6 B)$. Additionally, LDPCs reproducibly formed three dimensional duct-like structures when cultured in Matrigel (data not shown). LDPCs themselves did not produce urea or albumin in vitro. When LDPCs were cultured for 4 weeks in hepatogenic differentiation media, urea and albumin were secreted in the supernatant (Fig. 7A and B).

\section{Hematopoietic Potential of LDPCs}

As LDPCs express multiple markers commonly found on hematopoietic progenitors, we investigated whether LDPCs have hematopoietic potential in vitro by methylcellulose colony forming assay, and coculture with stromal cell lines shown to support hematopoeitic cultures. ${ }^{37,38}$ In all experiments, LDPCs fail to differentiate 


\section{Correlation Analysis of LDPC Microarray}

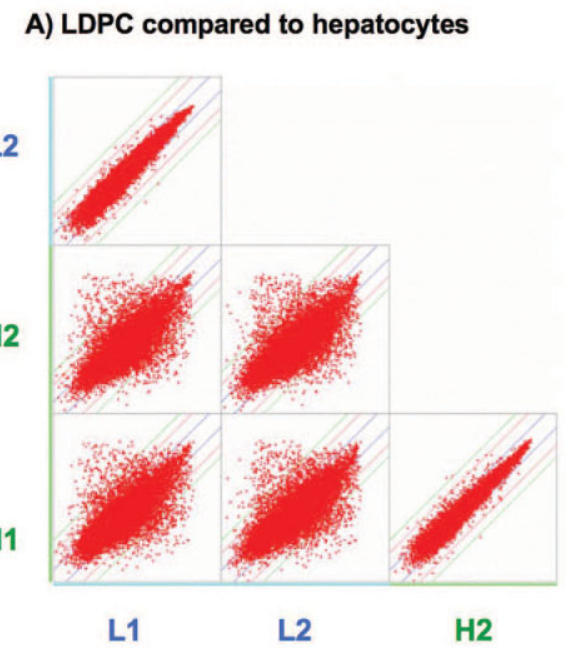

C) Gene Ontology Analysis

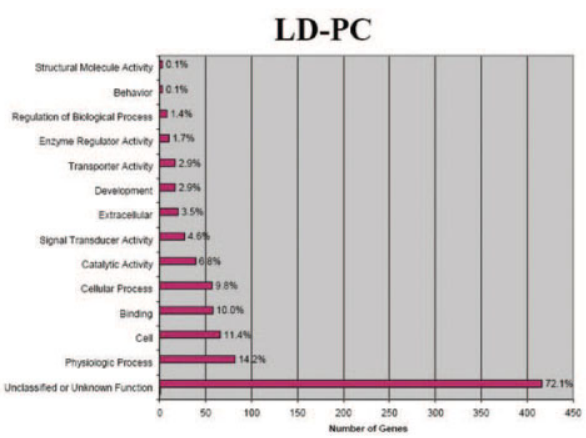

B) Correlation Analysis

\begin{tabular}{|c|c|c|c|c|c|c|c|c|c|}
\hline & L1 & L2 & L3 & L4 & L5 & H1 & H2 & H3 & H4 \\
\hline L1 & - & 0.97 & 0.95 & 0.95 & 0.92 & 0.70 & 0.73 & 0.71 & 0.72 \\
\hline L2 & 0.97 & - & 0.95 & 0.90 & 0.93 & 0.70 & 0.73 & 0.71 & 0.72 \\
\hline L3 & 0.95 & 0.96 & - & 0.94 & 0.90 & 0.69 & 0.72 & 0.70 & 0.71 \\
\hline L4 & 0.95 & 0.95 & 0.95 & - & 0.94 & 0.69 & 0.72 & 0.71 & 0.71 \\
\hline L5 & 0.92 & 0.93 & 0.90 & 0.94 & - & 0.68 & 0.71 & 0.70 & 0.69 \\
\hline H1 & 0.70 & 0.70 & 0.69 & 0.69 & 0.68 & - & 0.95 & 0.95 & 0.96 \\
\hline H2 & 0.73 & 0.73 & 0.72 & 0.72 & 0.71 & 0.95 & - & 0.97 & 0.97 \\
\hline H3 & 0.71 & 0.71 & 0.70 & 0.71 & 0.70 & 0.95 & 0.97 & - & 0.97 \\
\hline H4 & 0.72 & 0.72 & 0.71 & 0.71 & 0.69 & 0.96 & 0.97 & 0.97 & - \\
\hline
\end{tabular}

Legend

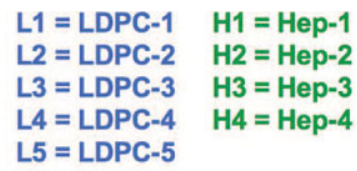

L5 = LDPC-5

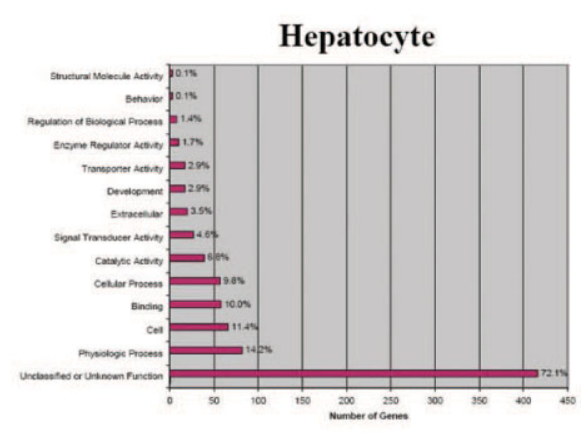

Figure 5. Microarray analysis of 5 separately isolated liver-derived progenitor cells (LDPCs) and hepatocyte samples. (A) Log-log plot comparing representative LDPC and hepatocyte samples. (B) Correlation ratios of LDPCs and hepatocyte samples. (C) Gene ontology analysis of more highly expressed genes in LDPC and hepatocytes. [Color figure can be viewed in the online issue, which is available at www.interscience.wiley.com.]

into hematopoietic lineages as demonstrated by lack of erythroid, granulocytic, and lymphoid lineage markers. We also transplanted LDPCs and rat BM in Rag2/ $\gamma_{c}$ null mice to determine their in vivo hematopoietic potential. Flow cytometric analysis of peripheral blood and BM did not demonstrate LDPC-derived blood cells ( $\mathrm{n}=15$ animals) whereas control animals transplanted with rat $\mathrm{BM}$ showed evidence of rat hematopoiesis by flow cytometry ( $\mathrm{n}=10$ animals; Supplemental Fig. 1).

\section{DISCUSSION}

Here we report isolation and characterization of a novel population of progenitor cells derived from uninjured adult rat liver, termed LDPCs or liver derived progenitor cells. The method we used to isolate LDPCs requires no chemicals or toxins in contrast to commonly used protocols for oval cell isolation ${ }^{13,17,39}$ which frequently result in chromosomal abnormalities in oval cells precluding their clinical application.

LDPCs are, like oval cells, ${ }^{13,17,39-41} \mathrm{HNF}-3 \beta, \mathrm{CD} 45$,
CD34, c-kit, and Thy-1 positive. In contrast to oval cells, LDPCs are negative for OV-6, CK7, and CK19 and express virtually no AFP. Clonally-derived LDPCs also exhibit an identical profile. Thus, the phenotype of LDPCs shows some similarities to that of oval cells. Like oval cells, LDPCs differentiate into both hepatocytes and ductal cells in vitro suggesting that LDPCs are bipotent progenitors, although without clonal differentiation experiments a definitive conclusion can not be drawn regarding their bipotentiality. Such studies are currently underway.

As LDPCs express CD34, CD45, c-Kit, Runx1, and Lmo2, markers traditionally associated with hematopoietic cells, we wanted to exclude the possibility of a hematopoietic origin (not BM origin) and investigated this possibility vigorously by in vitro and in vivo experiments. In these studies, LDPCs did not demonstrate any hematopoietic potential. The results of these studies, along with PCR and microarray data which show expression of a number of endodermal and hepatic 
A)

Day 7

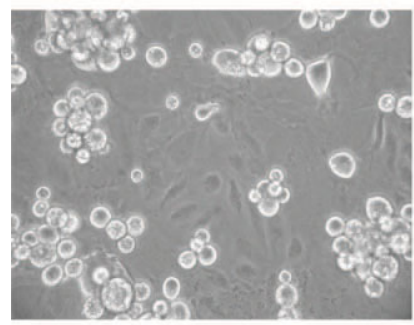

Day 14

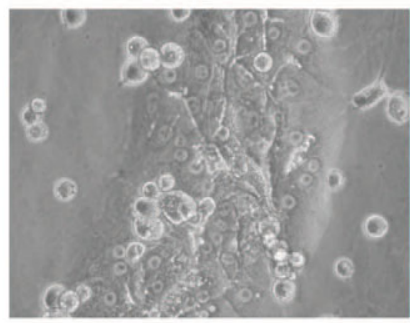

Day 28

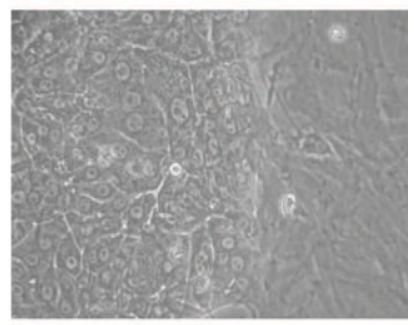

B)

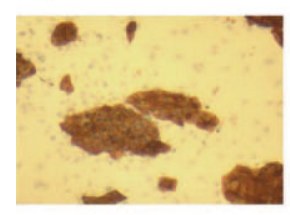

CK-18

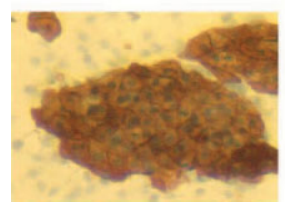

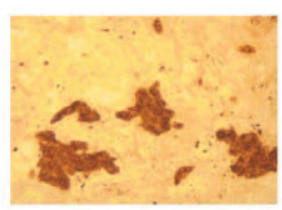

Albumin

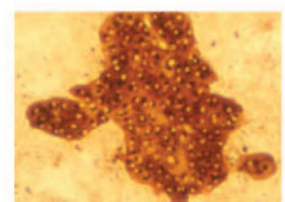

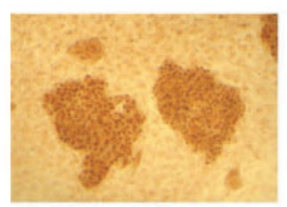

HNF1-Alpha

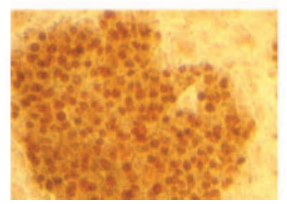

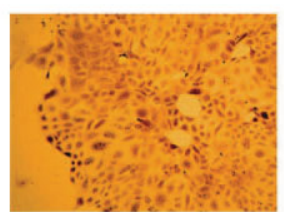

CK-19

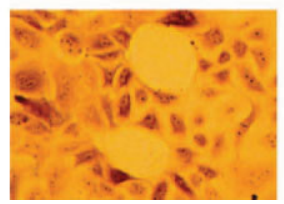

Figure 6. (A) In hepatic differentiation medium, liver-derived progenitor cells (LDPCs) undergo a series of morphological changes. Between days 5 and 7 , fibroblast-like cells appear in the culture, then around day 14 small clusters of hepatocytes emerge from these cells, followed by expansion of the clusters. At day 28,10 to $20 \%$ of the cells have hepatocyte morphology, the rest are fibroblast-like cells and few LDPCs. (B) On day 28, the hepatocyte clusters were analyzed by immunohistochemistry analysis (IHC). The clusters were positive for cytokeratin (CK)-18 albumin and hepatocyte nuclear factor (HNF)-1 $\alpha$, confirming that they were hepatocytes. They were negative for CK-7 and CK-19 (not shown). In some cultures, LDPCs formed lumen-like structures where surrounding cells were positive for CK-19, a biliary ductal marker, in a perinuclear fashion (far right).

markers by LDPCs, strongly suggest that LDPCs do not have a hematopoietic origin. This is in line with the recent observation by many groups that such presumed hematopoietic stem cell specific markers are not uniquely expressed by hematopoietic cells but by many other stem cells, progenitor cells and differentiated cells including oval cells.

Microarray analysis of LDPCs further supports the notion that LDPCs represent a population of hepatic progenitors, as the transcriptome of LDPCs is highly similar to that of oval cells. Many of the genes found to be highly expressed in LDPCs are also expressed in other hepatic stem cells, such as oval cells, during liver regeneration. For instance, Annexin A1 and A2, 2 of the most differentially expressed genes, are up-regulated during liver regeneration and hepatocyte proliferation. ${ }^{42}$ Other genes important in oval cell proliferation and liver regeneration such as genes influenced by IFN- $\gamma$ stimulation (gp91phox, caspase 1, urokinase plasminogen activator, IL-18, and IL-1 $\beta$ ) are abundantly expressed in LDPCs. In addition, LDPCs express many genes also identified in oval cells and other hepatic stem cell population whose role are uncertain; glutathione-s-transferase, pi isoform, 5-HT receptor, toll-like receptors 2 and 4, complement component 3
(C3A), complement component receptor 1 (C5A receptor), follistatin, vimentin, and connective tissue growth factor. ${ }^{43-49}$ Another interesting feature of LDPCs is the high level expression of CXCR4 which is an important chemokine receptor involved in homing of stem cells following their transplantation in vivo. ${ }^{50}$ In contrast, mature hepatocytes do not express any CXCR4 which suggests that LDPCs, having also a much smaller size, might be better suited for cell transplantation purposes than mature hepatocytes.

To put LDPCs in perspective, it might be helpful to compare them briefly with some of the other stem/ progenitor cell populations described in the literature. These cell populations can be divided into 2 main groups; those derived from fetal liver and those from post-natal liver. Relatively few groups have succeeded in isolating hepatic progenitors from noninjured postnatal liver. Mitaka et al. ${ }^{51}$ isolated cells, termed small hepatocytes, that can clonally proliferate to form large colonies of small cells that subsequently can be induced to differentiate to hepatocytes. ${ }^{52}$ Unlike LDPCs, small hepatocytes express hepatocyte specific genes such as albumin, CK8, CK18, and connexin $32 .{ }^{53}$ Nagai et al. ${ }^{54}$ also isolated cells from adult rat liver called HSL cells that, like LDPCs, are propagated on type I colla- 
A)

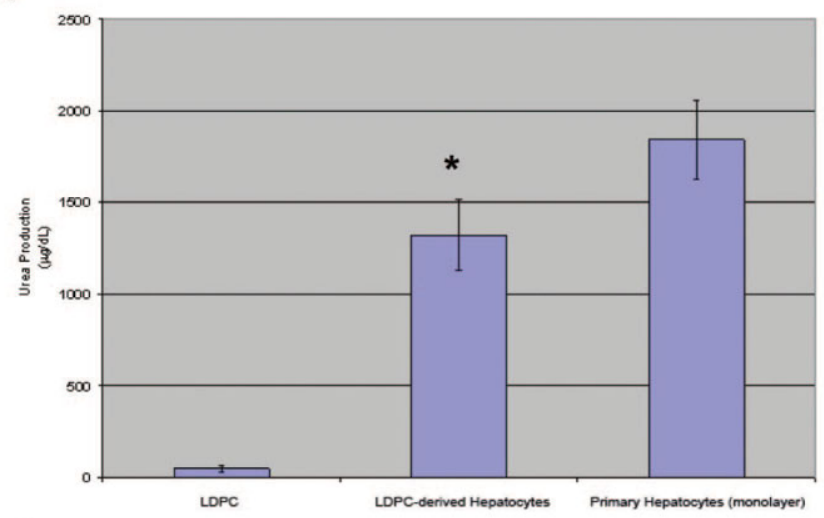

B)

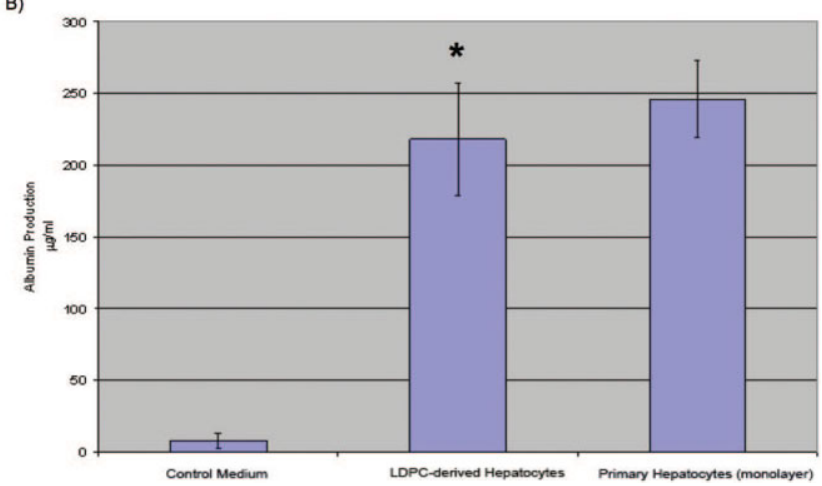

Figure 7. Liver-derived progenitor cells (LDPCs) do not produce urea whereas hepatocytes derived from LDPCs produce urea. Because the assay measures ammonia metabolized from urea, samples were assessed before and after urease addition. No urea or ammonia was detected in culture medium alone (A) LDPC-derived hepatocytes produce albumin (B). Studies were done in triplicate and repeated twice. Due to the nature of culture conditions, data for LDPC reflect the levels in 2 week old media, whereas data for primary hepatocytes were obtained from 24 hour old cultures.

gen, do not express albumin, CK18 and CK19, but unlike LDPCs, they clearly have an epithelial morphology and express high levels of AFP. Tateno et al. ${ }^{55}$ examined another cell type that also grows in clusters and expresses some mature hepatocyte markers such as CK8, CK18 and albumin but unlike small hepatocytes also express AFP. More recently, Fougere-Deschatrette et al. ${ }^{56}$ reported a clonal cell line derived from adult mouse liver, termed bipotential adult mouse liver cells, which is capable of differentiating into both hepatic and biliary lineages. These cells, in contrast to LDPCs, are CK19 positive and express number of markers found in mature hepatocytes.

Among the adult stem cell populations described in the literature, perhaps the one that is most closely related to LDPCs has been reported in rats treated with allyl alcohol by Sell et al. ${ }^{28}$ In the periportal regenerative zones, these investigators found several population of cells which appeared in response to injury. One population called "periportal small stem cells" were negative for CK, AFP, OV-6 and desmin similar to LDPCs but they did not express CD45 (LCA) in contrast to LDPCs. Because of the nature of the experiment; however, these cells could not be extensively examined for the expression of other stem cell markers, which makes it difficult to fully compare them with LDPCs. This difficulty exists for most of the adult liver progenitors described in the literature. Nevertheless, based on the available information, it is clear that LDPCs represent a different and possibly a less differentiated cell type than those described above.

There are also a number of embryonal/fetal liver progenitors described in the literature.

Suzuki et al. ${ }^{29,30}$ isolated hepatic stem cells from the

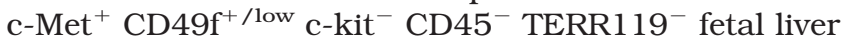
fraction. These cells possess the ability to differentiate into hepatocytes, biliary duct, pancreatic ductal cells, and the intestinal epithelium suggesting that they may be endodermal stem cells. Similar cells could also be isolated from fetal pancreas and liver of newborn mice. ${ }^{29,30}$ In addition to phenotypic differences between these cells and LDPCs, currently we have no evidence that LDPCs have extrahepatic potential. Another fetal progenitor population was described by Lazaro et al. ${ }^{31}$ Termed human fetal hepatocytes, these cells were positive for stem cell markers CD34 and Thyl but in contrast to LDPCs they expressed OV6, CK18, CK19 and AFP. More recently, Dan et al. ${ }^{57}$ described a new progenitor population derived from human fetal liver which were positive for a number of stem cell markers similar to LDPCs but unlike LDPCs they were CK18 and CK19 positive and they were capable of mesenchymal differentiation. Obviously the major distinction of LDPCs from these fetal cell populations is their presence in the liver of post-natal and older adult animals which is potentially a clinical advantage especially in cell transplantation for liver diseases.

The origin of LDPCs, at this time, is not clear. The absence of CK expression, which is present in virtually all adult liver stem/progenitor cells previously described, indicate that LDPCs are nonepithelial progenitors and probably more primitive than oval cells. As such they may exist in the nonparenchymal fraction of the liver cells or they may originate from an extrahepatic site. Even though they are cultured out of uninjured adult liver in a relatively short period of time in large numbers suggesting that they reside in the liver, we can not rule out the possibility of an extrahepatic origin such as BM without lineage-tracing studies. We are currently planning studies that will conclusively show their origin and animal studies designed to test their hepatic potential.

We conclude that LDPCs are a novel population of liver progenitors with some similarities to oval cells and hematopoietic stem cells. LDPCs can be generated highly reproducibly from unmanipulated and uninjured adult liver which makes them potentially useful for clinical applications as well as research purposes.

\section{ACKNOWLEDGMENTS}

We thank Scott Soltis for help with hepatocyte isolation and Jingbo Du and Todd Lenvik for their assistance with the microarray setup and analysis. We also thank 
Dr. Stewart Sell for supplying OV-1 and OV-6 antibodies, and Dr. Clifford Steer for his help with the revision of the manuscript.

\section{REFERENCES}

1. Bauer M, Winning J, Kortgen A. Liver failure. Curr Opin Anaesthesiol 2005;18:111-116.

2. Grompe M. Liver repopulation for the treatment of metabolic diseases. J Inherit Metab Dis 2001;24:231-244.

3. Sell S. Heterogeneity and plasticity of hepatocyte lineage cells. Hepatology 2001;33:738-750.

4. Fausto N. Liver regeneration: from laboratory to clinic. Liver Transpl 2001;7:835-844.

5. Michalopoulos GK, DeFrances MC. Liver regeneration. Science 1997;276:60-66.

6 . Sell S. The role of progenitor cells in repair of liver injury and in liver transplantation. Wound Repair Regen 2001;9: 467-482.

7. Oh SH, Hatch HM, Petersen BE. Hepatic oval 'stem' cell in liver regeneration. Semin Cell Dev Biol 2002;13:405-409.

8. Shiojiri N, Lemire JM, Fausto N. Cell lineages and oval cell progenitors in rat liver development. Cancer Res 1991;51: 2611-2620.

9. Evarts RP, Nagy P, Marsden E, Thorgeirsson SS. A precursor-product relationship exists between oval cells and hepatocytes in rat liver. Carcinogenesis 1987;8:17371740.

10. Evarts RP, Nagy P, Nakatsukasa H, Marsden E, Thorgeirsson SS. In vivo differentiation of rat liver oval cells into hepatocytes. Cancer Res 1989;49:1541-1547.

11. Baumann U, Crosby HA, Ramani P, Kelly DA, Strain AJ. Expression of the stem cell factor receptor c-kit in normal and diseased pediatric liver: identification of a human hepatic progenitor cell? Hepatology 1999;30:112-117.

12. Roskams T, De Vos R, Van Eyken P, Myazaki H, Van Damme B, Desmet V. Hepatic OV-6 expression in human liver disease and rat experiments: evidence for hepatic progenitor cells in man. J Hepatol 1998;29:455-463.

13. Petersen BE, Goff JP, Greenberger JS, Michalopoulos GK. Hepatic oval cells express the hematopoietic stem cell marker Thy-1 in the rat. Hepatology 1998;27:433-445.

14. Omori N, Omori M, Evarts RP, Teramoto T, Miller MJ, Hoang TN, Thorgeirsson SS. Partial cloning of rat CD34 cDNA and expression during stem cell-dependent liver regeneration in the adult rat. Hepatology 1997;26:720727.

15. Hixson DC, Chapman L, McBride A, Faris R, Yang L. Antigenic phenotypes common to rat oval cells, primary hepatocellular carcinomas and developing bile ducts. Carcinogenesis 1997;18:1169-1175.

16. Forbes S, Vig P, Poulsom R, Thomas H, Alison M. Hepatic stem cells. J Pathol 2002;197:510-518.

17. Wang X, Foster M, Al-Dhalimy M, Lagasse E, Finegold M, Grompe M. The origin and liver repopulating capacity of murine oval cells. Proc Natl Acad Sci U S A 2003; 100(Suppl 1):11881-11888.

18. Petersen BE, Bowen WC, Patrene KD, Mars WM, Sullivan AK, Murase N, et al. Bone marrow as a potential source of hepatic oval cells. Science 1999;284:1168-1170.

19. Oh SH, Witek RP, Bae SH, Zheng D, JungY, Piscaglia AC, Petersen BE. Bone marrow-derived hepatic oval cells differentiate into hepatocytes in 2-acetylaminofluorene/partial hepatectomy-induced liver regeneration. Gastroenterology 2007;132:1077-1087.

20. Theise ND, Saxena R, Portman BC, Thung SN, Yee N, Chiriboga L, et al. The canals of Hering and hepatic stem cells in humans. Hepatology 1999;30:1425-1433.
21. Theise ND, Nimmakayalu M, Gardner R, Illei PB, Morgan $\mathrm{G}$, Teperman L, et al. Liver from bone marrow in humans. Hepatology 2000;32:11-16.

22. Sell S. Cellular origin of cancer: dedifferentiation or stem cell maturation arrest? Environ Health Perspect 1993; 101(Suppl 5):15-26.

23. Sell S. Liver stem cells. Mod Pathol 1994;7:105-112.

24. Fang CH, Gong JQ, Zhang W. Function of oval cells in hepatocellular carcinoma in rats. World $J$ Gastroenterol 2004; 10:2482-2487.

25. Dumble ML, Croager EJ, Yeoh GC, Quail EA. Generation and characterization of p53 null transformed hepatic progenitor cells: oval cells give rise to hepatocellular carcinoma. Carcinogenesis 2002;23:435-445.

26. Roskams T, Yang SQ, Koteish A, Durnez A, DeVos R, Huang $\mathrm{X}$, et al. Oxidative stress and oval cell accumulation in mice and humans with alcoholic and nonalcoholic fatty liver disease. Am J Pathol 2003;163:1301-1311.

27. Seglen PO. Preparation of isolated rat liver cells. Methods Cell Biol 1976;13:29-83.

28. Yavorkovsky L, Lai E, Ilic Z, Sell S. Participation of small intraportal stem cells in the restitutive response of the liver to periportal necrosis induced by allyl alcohol. Hepatology 1995;21:1702-1712.

29. Suzuki A, Zheng YW, Kaneko S, Onodera M, Fukao K, Nakauchi H, Taniguchi H. Clonal identification and characterization of self-renewing pluripotent stem cells in the developing liver. J Cell Biol 2002;156:173-184.

30. Suzuki A, Zheng Y, Kondo R, Kusakabe M, Takada Y, Fukao K, et al. Flow-cytometric separation and enrichment of hepatic progenitor cells in the developing mouse liver. Hepatology 2000;32:1230-1123.

31. Lazaro CA, Croager EJ, Mitchell C, Campbell JS, Yu C, Foraker J, et al. Establishment, characterization, and long-term maintenance of cultures of human fetal hepatocytes. Hepatology 2003;38:1095-1106.

32. Stappenbeck TS, Mills JC, Gordon JI. Molecular features of adult mouse small intestinal epithelial progenitors. Proc Natl Acad Sci U S A 2003;100:1004-1009.

33. Lee HS, Sherley JL, Chen JJ, Chiu CC, Chiou LL, Liang JD, et al. EMP-1 is a junctional protein in a liver stem cell line and in the liver. Biochem Biophys Res Commun 2005; 334:996-1003.

34. Cimica V, Batusic D, Chen Y, Hollemann T, Pieler T, Ramadori G. Transcriptome analysis of rat liver regeneration in a model of oval hepatic stem cells. Genomics 2005;86: 352-364.

35. Wang C, Chelly MR, Chai N, Tan Y, Hui T, Li H, et al. Transcriptomic fingerprinting of bone marrow-derived hepatic beta2m-/Thy-1+ stem cells. Biochem Biophys Res Commun 2005;327:252-260.

36. Mills JC, Andersson N, Hong CV, Stappenbeck TS, Gordon JI. Molecular characterization of mouse gastric epithelial progenitor cells. Proc Natl Acad Sci U S A 2002;99:1481914824.

37. Moore KA, Ema H, Lemischka IR. In vitro maintenance of highly purified, transplantable hematopoietic stem cells. Blood 1997;89:4337-4347.

38. Oostendorp RA, Harvey KN, Kusadasi N, de Bruijn MF, Saris C, Ploemacher RE, et al. Stromal cell lines from mouse aorta-gonads-mesonephros subregions are potent supporters of hematopoietic stem cell activity. Blood 2002;99:1183-1189.

39. Matsusaka S, Toyosaka A, Nakasho K, Tsujimura T, Sugihara A, Takanashi T, et al. The role of oval cells in rat hepatocyte transplantation. Transplantation 2000;70:441-446.

40. Petersen BE. Hepatic "stem" cells: coming full circle. Blood Cells Mol Dis 2001;27:590-600. 
41. Vessey CJ, de la Hall PM. Hepatic stem cells: a review. Pathology 2001;33:130-141.

42. Della Gaspera B, Braut-Boucher F, Bomsel M, Chatelet F, Guguen-Guillouzo C, Font J, et al. Annexin expressions are temporally and spatially regulated during rat hepatocyte differentiation. Dev Dyn 2001;222:206-217.

43. Pi L, Oh SH, Shupe T, Petersen BE. Role of connective tissue growth factor in oval cell response during liver regeneration after $2-\mathrm{AAF} / \mathrm{PHx}$ in rats. Gastroenterology 2005; 128:2077-2088.

44. Campbell JS, Riehle KJ, Brooling JT, Bauer RL, Mitchell C, Fausto N. Proinflammatory cytokine production in liver regeneration is Myd88-dependent, but independent of Cd14, Tlr2, and Tlr4. J Immunol 2006;176: 2522-2528.

45. Lesurtel M, Graf R, Aleil B, Walther DJ, Tian Y, Jochum W, et al. Platelet-derived serotonin mediates liver regeneration. Science 2006;312:104-107.

46. Markiewski MM, Mastellos D, Tudoran R, DeAngelis RA, Strey CW, Franchini S, et al. C3a and C3b activation products of the third component of complement (C3) are critical for normal liver recovery after toxic injury. J Immunol 2004; 173:747-754.

47. Daveau M, Benard M, Scotte M, Schouft MT, Hiron M, Francois A, et al. Expression of a functional C5a receptor in regenerating hepatocytes and its involvement in a proliferative signaling pathway in rat. J Immunol 2004;173: 3418-3424.

48. Endo D, Maku-Uchi M, Kojima I. Activin or follistatin: which is more beneficial to support liver regeneration after massive hepatectomy? Endocr J 2006;53:73-78.

49. Haque S, Haruna Y, Saito K, Nalesnik MA, Atillasoy E, Thung SN, Gerber MA. Identification of bipotential pro- genitor cells in human liver regeneration. Lab Invest 1996; 75:699-705.

50. Chute JP. Stem cell homing. Curr Opin Hematol 2006; 13: 399-406.

51. Mitaka T, Norioka K, Nakamura T, Mochizuki Y. Effects of mitogens and co-mitogens on the formation of small-cell colonies in primary cultures of rat hepatocytes. J Cell Physiol 1993;157:461-468.

52. Sudo R, Mitaka T, Ikeda M, Tanishita K. Reconstruction of 3D stacked-up structures by rat small hepatocytes on microporous membranes. FASEB J 2005; 19:1695-1697.

53. Mitaka T, Mizuguchi T, Sato F, Mochizuki C, Mochizuki Y. Growth and maturation of small hepatocytes. J Gastroenterol Hepatol 1998;13(Suppl):S70-S77.

54. Nagai H, Terada K, Watanabe G, Ueno Y, Aiba N, Shibuya T, et al. Differentiation of liver epithelial (stemlike) cells into hepatocytes induced by coculture with hepatic stellate cells. Biochem Biophys Res Commun 2002;293:1420-1425.

55. Tateno C, Yoshizato K. Growth and differentiation in culture of clonogenic hepatocytes that express both phenotypes of hepatocytes and biliary epithelial cells. Am J Pathol 1996;149:1593-1605.

56. Fougere-Deschatrette $C$, Imaizumi-Scherree $T$, StrickMarchand H, Morosan S, Charneau P, Kremsdorf D, et al. Plasticity of hepatic cell differentiation: bipotential adult mouse liver clonal cell lines competent to differentiate in vitro and in vivo. Stem Cells 2006;24:20982109.

57. Dan YY, Riehle KJ, Lazaro C, Teoh N, Haque J, Campbell JS, Fausto N. Isolation of multipotent progenitor cells from human fetal liver capable of differentiating into liver and mesenchymal lineages. Proc Natl Acad Sci U S A 2006;103:9912-9917. 